\title{
REORIENTACJA STRUKTURY PODMIOTOWEJ GLOBALNYCH PRZEPLYWÓW BEZPOŚREDNICH INWESTYCJI ZAGRANICZNYCH W CZASIE KRYZYSU FINANSOWEGO 2008+
}

\begin{abstract}
Streszczenie
W artykule podjęto dyskusję na temat wpływu uwarunkowań koniunkturalnych na: dynamikę, strukturę podmiotową i kierunki globalnych przepływów bezpośrednich inwestycji zagranicznych w gospodarkach o różnym stopniu rozwoju. W tym celu dokonano analizy empirycznej przepływów i wartości skumulowanej FDI z wykorzystaniem wybranych metod statystycznych i wskaźników (korelacji, struktury, dynamiki, otwartości gospodarki), którą wsparto informacjami dotyczącymi zmian makroekonomicznych w wybranych grupach krajów w latach 2006-2012. Przeprowadzone badania dowiodły transpozycji w strukturze podmiotowej FDI na korzyść krajów rozwijających się. Wiązała się z tym aktywność inwestycyjna w tej grupie państw, charakteryzująca się wysokim poziomem otwartości na inwestycje oraz zależności od wzrostu zagregowanego PKB i handlu międzynarodowego.
\end{abstract}

Słowa kluczowe: bezpośrednie inwestycje zagraniczne, kraje rozwinięte, kraje rozwijające się, dekoniunktura

\section{RE-ORIENTATION OF ENTITY STRUCTURE OF FOREIGN DIRECT INVESTMENT FLOWS DURING FINANCIAL CRISIS 2008 (AND ONWARDS)}

\section{Summary}

The paper discusses the impact of economic conditions on the dynamics of change, business breakdown structure and trends in foreign direct investments flows in economies on different levels of development. For this purpose, an empirical analysis of FDI flows and stocks is conducted. Selected statistical methods and indicators (of correlation, structure, dynamics, openness of economy) are used. The analysis is supported with information regarding macroeconomic changes in selected groups of countries between 2006 and 2012. The study has revealed a transposition in the structure of FDI in favour of developing countries. This was partly an effect of investment activity in this group of countries, characterised by a high level of readiness for investments and strong dependence on the growth of aggregate GDP and international trade.

Key words: foreign direct investment, developed economies, developing economies, downturn

JEL Classification: F20, F01, O57 


\section{Wstęp}

Wzrost powiązań i współzależności we współczesnej gospodarce światowej to efekt procesu globalizacji. Czynnikiem intensyfikującym zachodzące zmiany jest postępująca internacjonalizacja działalności gospodarczej, realizowana przez przedsiębiorstwa w formie bezpośrednich inwestycji zagranicznych (Foreign Direct Investment - FDI). Zgodnie z definicją IMF, OECD i UNCTAD, wiążą się one z powstaniem długotrwałych relacji i istotnego poziomu oddziaływania między inwestorem bezpośrednim a przedsiębiorstwem bezpośredniej inwestycji ${ }^{1}$. Zatem niezmiernie ważne znaczenie w prowadzeniu działalności w skali międzynarodowej i globalnej ma transfer kapitału, który w kontekście makroekonomicznym stanowi zewnętrzne źródło finansowania gospodarki danego kraju. Jest on jednak tylko jednym z wielu elementów całego pakietu wartości transferowanych, wśród których obecnie szczególną rolę odgrywaja: technologia, metody organizacji i zarządzania, a także systemy marketingowe. Najczęściej są one podejmowane jako element strategii zarządzania skierowanej w stronę rozwoju poprzez ekspansję na rynek światowy, dającą dodatkowe szanse zarówno na bardziej racjonalne wykorzystanie aktywów, jak i uzyskanie przewagi nad konkurentami. Możliwości te stwarzaja przede wszystkim odmienne w poszczególnych krajach uwarunkowania związane z klimatem inwestycyjnym oraz różnice w geograficznym rozmieszczeniu i jakości czynników produkcji na świecie. Zainteresowanie inwestorów jest więc zależne od: przedmiotu działalności, możliwości finansowych, poziomu atrakcyjności inwestycyjnej i sytuacji gospodarczej regionu [Kamińska-Blichowska, 2016, s. 4-5]. Duże znaczenie mają zatem w równej mierze czynniki o charakterze makroekonomicznym, jak i szereg czynników o charakterze mikroekonomicznym [Różański, 2014, s. 353].

Ze względu na determinanty internacjonalizacji działalności oraz wysoki stopień intensywności powiązań w skali światowej wydaje się oczywiste, że istnieje ścisła koincydencja między sytuacją w gospodarce światowej a intensywnością FDI, ujawniająca tym samym kumulatywny proces zmian. Implikacje współczesnego, globalnego kryzysu gospodarczego, zapoczątkowanego w 2008 roku w Stanach Zjednoczonych, odnosiły się tak do samych przedsiębiorstw m.in. w postaci zaostrzonych warunków kredytowych czy obniżenia rentowności, jak i do gospodarek poszczególnych krajów zmuszonych do reorientacji polityki ekonomicznej. Czy w takiej sytuacji, biorąc pod uwagę fakt, iż powszechnie inwestycje są oceniane jako najbardziej bezpieczna forma

1 Foreing Direct Investment (FDI) jest kategoria międzynarodowych inwestycji dokonywana przez rezydenta jednego kraju, nazywanego inwestorem bezpośrednim lub firmą matka, jak również korporacja transnarodowa (KTN), z zamiarem sprawowania długotrwałej kontroli w przedsiębiorstwie innego kraju, nazywaną przedsiębiorstwem bezpośredniej inwestycji (PBI) lub firmą-córka. Minimalny próg zaangażowania kapitałowego inwestora bezpośredniego w przedsiębiorstwie bezpośredniej inwestycji, celem uznania inwestycji za FDI, ustalono na poziomie $10 \%$. Inwestycje o niższym udziale inwestora zagranicznego sa kwalifikowane jako inwestycje portfelowe [World Investment Report..., 2007, s. 245; Glossary of foreign direct investment..., s. 7-8]. 
lokowania kapitału 2 , okres dekoniunktury wywołał zmiany w przepływach FDI porównywalne do spowolnienia wzrostu gospodarczego czy międzynarodowej wymiany handlowej? Trudno na to pytanie odpowiedzieć w sposób jednoznacznie twierdzący, gdyż inwestycje są realizowane w różnych sektorach gospodarki mniej lub bardziej odpornych na wahania czynników ekonomicznych ${ }^{3}$. Różna jest zatem ich otwartość na inwestycje.

W związku z tym, można przyją́ założenie, że przeobrażenia ilościowe i jakościowe w globalnych przepływach FDI są odmienne dla poszczególnych sektorów i regionów. Na tym tle pojawiają się więc pytania: czy i w jaki sposób uwarunkowania dekoniunktury determinowały dynamikę i kierunki przepływów FDI, w jakim stopniu były z nimi skorelowane, czy i jaka jest różnica w poziomie otwartości gospodarek na pozyskanie zewnętrznego źródła finansowania w postaci inwestycji, oraz czy w przypadku zaistnienia zmian mają one charakter trwały i utrzymały się również w fazie względnego ożywienia? Uzyskanie odpowiedzi na postawione pytania stanowi cel niniejszego opracowania.

\section{Materiał i metodyka badań}

Realizacji celu posłużyła analiza empiryczna ex post (2006-2012) przepływów FDI z wykorzystaniem wybranych metod statystycznych. Zastosowano miary zależności (współczynnik korelacji Pearsona) oraz wskaźniki struktury i dynamiki, w tym średnioroczne tempo zmian. Jednocześnie obliczono miernik otwartości gospodarki na inwestycje w relacji do produktu krajowego brutto (Gross Domestic Product GDP).

Podstawowe źródło stanowiła internetowa baza danych statystycznych (http:// unctadstat.unctad.org/) oraz raporty Konferencji Narodów Zjednoczonych do spraw Handlu i Rozwoju (United Nations Conference on Trade and Development UNCTAD), w tym zwłaszcza World Investment Report (WIR) regularnie publikowane przez UNCTAD. Dlatego też badane grupy krajów (kraje rozwinięte i rozwijające się) odpowiadają klasyfikacji i kryteriom stosowanym przez UN.

2 Poglądy ekonomistów na temat wpływu FDI na procesy wzrostu gospodarczego są zróżnicowane, chociaż w większości są traktowane jako najbardziej korzystna i bezpieczna forma międzynarodowych przepływów kapitałowych [Ptaszyńska, 2015, s. 27]. Wynika to głównie z długookresowego charakteru tego rodzaju inwestycji, który nie niesie ze sobą niebezpieczeństwa zastosowania strategii bit and run, polegającej na nagłym wtargnięciu i natychmiastowym wycofaniu się z gałęzi po osiągnięciu przejściowego zysku [Wyrzykowska, 2010, s. 180].

3 Przykładem może być branża spożywcza, która jako jedna z nielicznych jest zdolna wypracować dodatnie wyniki finansowe podczas recesji, gdyż w strukturze przedmiotowej przeważaja produkty podstawowe, których popyt jest nieelastyczny. Dodatkowo, dla wielu krajów mają one znaczenie strategiczne, stanowiąc swego rodzaju „broń ekonomiczną” gwarantująca zaspokojenie potrzeb bezpieczeństwa żywnościowego. 


\section{Przegląd literatury}

W krajowej i zagranicznej literaturze ekonomicznej znajduje się wiele opracowań dotyczących bezpośrednich inwestycji zagranicznych. Uwarunkowania wymiany kapitału, motywy i efekty napływu oraz ich znaczenie dla gospodarki kraju przyjmujaccego były przedmiotem rozważań m.in.: J. Misali [1990], A. Zorskiej [1998], J. Witkowskiej [1996], E. Oziewicz [1998], W. Karaszewskiego [2004], J. Rymarczyka [2004], A. Kłysik-Uryszek [2010], J. Świerkockiego [2011] czy R. Oczkowskiej [2013]. Ważną okolicznością, która wymagała uwzględnienia w kontekście podjętej problematyki, są relacje między przepływem kapitału w formie bezpośrednich inwestycji zagranicznych a wzrostem gospodarczym. Szczególną rolę w tym obszarze odgrywa dorobek J.H Dunninga [1998], autora teorii kształtowania się pozycji inwestycyjnej na rynkach zagranicznych, w której, zgodnie z przyjętym modelem, w miarę rozwoju gospodarczego następuje zmiana zarówno w wolumenie napływu i odpływu FDI, jak i w ich strukturze. Bezpośrednie inwestycje zagraniczne stanowią uzupełnienie inwestycji krajowych, zazwyczaj skutkują zwiększonymi możliwościami zatrudnienia oraz importem technologii, co prowadzi do wzrostu gospodarczego w kraju przyjmującym [Chowdhury, Mavrotas, 2006, za: Misztal, 2012, s. 15]. Zbliżone podejście reprezentują: E. Borensztein, J. De Gregorio, J.W. Lee, którzy udowodnili, że napływ FDI pociaga za soba napływ technologii, a jej wykorzystanie przekłada się na szybszy wzrost gospodarczy kraju przyjmującego kapitał, ale tylko wtedy, gdy kraj osiaga tzw. minimalny próg zasobów kapitału ludzkiego [Borensztein, Gregoriob, Lee, 1998, s. 115]. Współzależności między międzynarodową mobilnością kapitału a rozwojem gospodarczym również rozpatrywali: J.J. Michałek, M. Brzozowski, A. Cieślik [2012, za: Gorynia, 2016, s. 208]. Zdaniem P. Misztala, większość wyników przeprowadzonych analiz makroekonomicznych wskazuje na związki między FDI a wzrostem gospodarczym, a jednocześnie sugeruje występowanie relatywnie mało istotnego wpływu bezpośrednich inwestycji zagranicznych na dynamikę rozwoju gospodarczego ${ }^{4}$ [Misztal, 2012, s. 15].

Pomimo dużego zainteresowania naukowców zależnością między FDI a wzrostem gospodarczym, w opinii M. Wang i M.C. Sunny Wong, w literaturze nadal nie ma jednoznaczności co do charakteru interakcji między nimi. Badania prowadzone dla 84 krajów w latach 1987-2001 wskazały na odmienne reakcje wzrostu na inwestycje typu greenfield (dodatnia) oraz fuzji i przejęć M\&A (ujemna) [Wang, Wong, 2009 , s. 327-328]. Ważnym komponentem w tym dyskursie staje się opracowanie P. Folfasa, które dotyczy związku między strumieniami napływających FDI a wzrostem realnego PKB w dziesięciu państwach, tj.: we Francji, w Japonii, Niemczech, USA i Wielkiej Brytanii oraz w Brazylii, Chinach, Indiach, Rosji i RPA w latach 1971-2012. Na podstawie przeprowadzonych testów przynajmniej jednokierunkowa przyczynowość została potwierdzona tylko w dwóch badanych krajach (w Japonii

$4 \quad$ Wyniki badań przeprowadzonych dla Polski potwierdziły pozytywny i istotny wpływ zagranicznych inwestycji bezpośrednich na dynamikę produktu krajowego brutto w Polsce, lecz czynnik ten okazał się najmniej znaczącą determinantą wzrostu gospodarczego [Misztal, 2012, s. 26]. 
i Indiach). Dlatego też, według P. Folfasa, zasadne jest stwierdzenie, że związek przyczynowo-skutkowy między napływami FDI a wzrostem realnego PKB jest kwestią indywidualną danej gospodarki i prawdopodobnie zależy od specyficznych czynników danej gospodarki goszczącej, a także od okresu analizy [Folfas, 2015, s. v30]. W opinii E.I. Markovskaya i E.S. Anoshkina, wpływ FDI na wzrost gospodarczy jest z pewnościa pozytywny, a wyniki ich badań potwierdziły to, że poziom tego efektu zależy od charakterystyki danego kraju [Markovskaya, Anoshkina, 2016, s. 14]. Dowody empiryczne sugerują skuteczność bezpośrednich inwestycji zagranicznych $\mathrm{w}$ podnoszeniu stopy wzrostu, przy czym jest ona zróżnicowana i wyższa w gospodarkach charakteryzujących się większą otwartością na handel [Nair-Reichert, Weinhold, 2001, s. 168].

Ocenę relacji między FDI a wzrostem gospodarczym również dokonali: M.V. Carkovic i R. Levine [2002], X. Li i X. Liu [2005], wskazując na niejednorodność wpływu i endogeniczne zależności z kapitałem ludzkim czy poziomem rozwoju technologicznego. Niejednoznaczność wzajemnych relacji pomiędzy wzrostem a przepływami kapitałowymi oraz ich uzależnienie od: rodzaju przepływów, struktury gospodarczej i globalnych wzorców wzrostu także podkreślali: J. Aizenman, Y. Jinjarak i D. Park [2013] na podstawie obserwacji około 100 krajów w latach 1990-2010. Badania empiryczne M. Żmudy, obejmujące gospodarkę Chin, pokazały, że PKB, otwartość na handel i bogactwo zasobów naturalnych są dodatnio skorelowane $z$ chińskim FDI, podczas gdy pozostałe zmienne, w tym ryzyko polityczne, wykazuja ujemną korelację [Żmuda, 2012, s. 97]. Pozytywną korelację przedstawili: X. Liu, P. Burridge i P.J.N. Sinclair, akcentując dwukierunkową zależność między wzrostem gospodarczym, FDI i eksportem [Liu, Burridge, Sinclair, 2002, s. 1433-40]. Dla Polski oddziaływanie BIZ na wzrost gospodarczy za pomoca analizy korelacji i regresji rozpatrywali m.in. A Majewska i J. Grala [2003]. Związki przyczynowe między inwestycjami zagranicznymi a podstawowymi wskánnikami makroekonomicznymi w Polsce również badali: H. Gurgul, Ł. Lach [2009], G. Ancyparowicz [2009], A.P. Balcerzak, M. Żurek [2010] oraz B. Marona, A. Bieniek [2013]. Natomiast analizę zmian, jakie wystapiły w latach 2006-2011 w strukturze światowego eksportu i importu, oraz międzynarodowych inwestycji bezpośrednich przeprowadziła R. Oczkowska [2013, s. 230-302], która zwróciła uwagę na wzrastającą rolę Chin i Brazylii w procesach umiędzynarodowienia przedsiębiorstw.

Przytoczone przykłady koncepcji i analiza opracowań teoretycznych i empirycznych dotyczących bezpośrednich inwestycji zagranicznych prowadzą do konkluzji, że eksporterami kapitału w formie FDI sa gospodarki rozwinięte, a kapital jest skierowany do gospodarek rozwijających się [Kłysik-Uryszek, 2013, s. 163]. Jednocześnie zarysowała się stała tendencja zwiększania się napływu BIZ do krajów rozwijających się, a zmniejszania w krajach rozwiniętych (niewatpliwie, na kryzysie finansowym zyskały kraje rozwijające się, w tym zwłaszcza kraje Azji, gdzie napływ BIZ był szczególnie widoczny). Jednakże warunkiem dużych i efektywnych transferów kapitałowych jest stabilna sytuacja gospodarczo-finansowa oraz polityczno-społeczna w świecie [Kamińska-Blichowska, 2016, s. 9]. W związku z tym, niepomierne znaczenie w rozpo- 
znaniu fluktuacji na światowym rynku inwestycji mają badania uwzględniające dywersyfikację krajów ze względu na poziom rozwoju gospodarczego.

Proces globalizacji sprawia, że kondycja gospodarcza kraju jest w pewnym stopniu uzależniona od koniunktury na rynku światowym. Zdaniem M. Goryni, kryzys zapoczątkowany w 2008 roku przede wszystkim wywołał egzogeniczne utrudnienia w prowzrostowym rozwoju gospodarki [Gorynia, 2016, s. 207]. Problematyka współczesnego kryzysu była rozpatrywana m.in.przez: G. Kołodkę [2010], T. Kowalskiego [2013] oraz w opracowaniu M. Dzikowskiej, M. Goryni, B. Jankowskiej [2015]. Wyjaśnienia przyczyn i mechanizmu kryzysu finansowego, którego geneza sięga połowy 2007 roku $^{5}$, kiedy to doszło do załamania kredytów hipotecznych typu subprime na amerykańskim rynku, również stały się przedmiotem badań: D. Rosati [2009], M. Krzak [2009], Z. Zioło [2014]. Rozważania łączące dekoniunkturę gospodarki światowej z sytuacją na rynku inwestycji bezpośrednich podjęli m.in.: A. KłysikUryszek [2012], K. Puchalska [2012], J. Różański [2013], M. Jasiniak [2014], M. Wypych [2016], dokonując oceny wpływu kryzysu gospodarczego na zmiany wartości, kierunków czy struktury FDI w Polsce. Badania w ujęciu regionalnym realizowała B. Pera [2012], która uwzględniła kraje Unii Europejskiej, a w szczególności kraje wschodniego rozszerzenia, a E. Bilewicz [2011] kraje rozwijające się. Według Różańskiego, doszło do dość daleko idącej realokacji kierunków (i wielkości) przepływów bezpośrednich inwestycji zagranicznych: od dłuższego czasu zmniejsza się rola państw Unii Europejskiej w tych procesach, zwiększa rola Chin, stabilizuje się rola USA i Rosji, a także zwiększa się rola Brazylii jako beneficjenta [Różański, 2014, s. 353]. Zdaniem A. Onufer, FDI, obok innych form aktywności gospodarczej, stały się jedną z ofiar kryzysu, przy czym charakteryzuja się one większą stabilnością niż inwestycje portfelowe czy inne formy inwestowania [Onufer, 2011, s. 885].

\section{Wyniki badań}

Od 2004 do 2006 roku można zaobserwować wzrost globalnych przepływów kapitałowych w formie FDI. Wówczas gospodarka światowa rozwijała się w dynamicznym tempie, osiagając wzrost na poziomie 4,11\% (w cenach stałych z 2005 roku). Wśród czynników intensyfikujących lokalizację działalności gospodarczej wymienia się utrzymujące się, niskie stopy procentowe w krajach wysoko rozwiniętych, w efekcie których nastąpił wzrost popytu wewnętrznego, jak również relatywnie stabilne otoczenie makroekonomiczne. Przyspieszenie napływu FDI (FDI inflows) dotyczyło wszystkich grup krajów, przy czym dwie trzecie inwestycji było realizowanych w gospodarkach rozwiniętych. Głównym ich odbiorcą były państwa Unii Europejskiej (Wielka

\footnotetext{
Ramy kryzysu gospodarczego objęły lata 2008-2010, choć jego korzenie sięgały okresu przed 2008 rokiem [Firlej, 2011, s. 180], podobnie jak pierwsze wyraźne symptomy kryzysu były znacznie wcześniej odczuwalne. Recesja w Stanach Zjednoczonych rozpoczęła się pod koniec 2007 roku (w grudniu 2007 roku), natomiast kryzys finansowy na dobre wybuchł 15 września 2008 roku wraz z upadkiem Lehman Brothers [Szydło, 2013, s. 3].
} 
Brytania, Francja, Belgia, Niemcy) oraz Stany Zjednoczone, a spośród krajów rozwijających się - Chiny, Brazylia i Meksyk [World Investment Report..., 2007, s. 3].

Dynamiczny wzrost poziomu inwestycji zagranicznych był efektem przeobrażeń w polityce gospodarczej, służących poprawie atrakcyjności inwestycyjnej ${ }^{6}$. Wyniki badań przeprowadzonych przez UNCTAD wskazały 184 zmiany w ustawodawstwie, z czego 109 zostało przyjętych przez rządy państw rozwijających się ${ }^{7}$. Decyzje te były jedną z przyczyn szybszego wzrostu wartości napływu FDI w grupie krajów rozwijających się i $(+36,4 \%)$ kosztem gospodarek rozwiniętych (+33,9\%) w 2007 roku. Najwyższe tempo zmian odnotowano w Ameryce Południowej, Środkowej i w Afryce.

Kapitał w formie inwestycji był transferowany w $81 \%$ przez firmy będące rezydentem krajów wysoko rozwiniętych, z czego dwie trzecie jednostek macierzystych była zlokalizowanych w Europie (we Francji, w Niemczech, Hiszpanii, Holandii, Wielkiej Brytanii). Ważnymi inwestorami były również przedsiębiorstwa pochodzące ze Stanów Zjednoczonych, których wartość FDI stanowiła prawie 16\% globalnych odpływów (FDI outflows). W krajach rozwijających się coraz większą rolę odgrywały firmy z Chin, których wartość bezpośrednich inwestycji zagranicznych w porównaniu z 2005 rokiem wzrosła o 60\%.

W 2007 roku korzystne uwarunkowania makroekonomiczne nadal sprzyjały rozwojowi zagranicznych inwestycji bezpośrednich (rysunek 1.). Stosunkowo wysoki wzrost gospodarczy $(4,03 \%)$, dalsze zmiany w polityce gospodarczej mające na celu poprawę atrakcyjności regionów, deprecjacja dolara, rosnąca wydajność i reinwestowane zyski [World Investment Report..., 2008, s. xv-xvi, 12] to jedne z wielu przyczyn rekordowego poziomu przepływów globalnych w skali świata (FDI oufflows $2272049 \mathrm{mln}$ USD, FDI inflows $2002695 \mathrm{mln}$ USD). Wzrost transferu kapitału objął wszystkie grupy krajów i regiony świata, przy czym coraz bardziej liczącym się obszarem lokalizacji były gospodarki rozwijające się, w przypadku których odnotowano wyższe tempo wzrostu wartości napływu FDI o 2,5 p.p. w porównaniu z państwami rozwiniętymi. Szczególne znaczenie wśród przyjmujących kapitał miały: Chiny, Singapur, Brazylia i Meksyk, a relatywnie największą dynamikę napływu odnotowano w przypadku: Tajlandii, Malezji, Malawi, Kenii i Tajwanu. Struktura geograficzna inwestorów nie uległa zasadniczym zmianom, mimo że coraz częściej dotychczasowi biorcy awansowali do roli dawców i głównie były to kraje Azji i Ameryki Południowej.

6 Ocena atrakcyjności poszczególnych krajów jest przeprowadzana na podstawie tzw. wskaźnika potencjalnego przyciagania FDI (Inward FDI Potencial Index), który UNCTAD oblicza dla 140 krajów, przy uwzględnieniu 12 czynników natury gospodarczej i politycznej.

7 W tym, w krajach Afryki - 57, a w Azji Południowo-Wschodniej - 32. Obejmowały one przede wszystkim wdrożenie nowych działań promocyjnych i zachęt, tj.: obniżenie podatku dochodowego (Egipt, Ghana, Singapur), stworzenie specjalnych stref ekonomicznych (Indie), wdrożenie tzw. przyspieszonych programów wzrostu (Brazylia) czy liberalizację rynku (Albania, Algieria, Bułgaria). Jednak w przypadku sektorów wrażliwych i strategicznych, mając na uwadze zapewnienie bezpieczeństwa ekonomicznego, kraje nadal utrzymywały wysoki stopień ochrony, a nawet wprowadzały nowe utrudnienia w stosunku do inwestorów zagranicznych (m.in.: Chiny, Peru, Boliwia, Wenezuela, Rosja, Macedonia) [World Investment Report..., 2007, s. 17-18]. 
Głównymi dawcami pozostały: Stany Zjednoczone, Wielka Brytania, Francja, Niemcy i Hiszpania.

Jednocześnie, w związku z niepewnością wywołaną sytuacją na rynku nieruchomości w Stanach Zjednoczonych i spowolnieniem amerykańskiej gospodarki, pojawiły się symptomy protekcjonizmu ukierunkowanego w stronę zwiększenia bezpieczeństwa finansowego. Był on zauważalny na poziomie mikro- i makroekonomicznym, zwłaszcza w drugiej połowie 2007 roku [World Investment Report..., 2007, s. 18]. Konsekwencje kryzysu finansowego uwidoczniły się w 2008 roku i to w odniesieniu do wszystkich wskaźników aktywności gospodarczej, w tym również w poziomie globalnych przepływów FDI. Wartość netto transferowanego kapitału w formie inwestycji bezpośrednich obniżyła się o 10,5\% w stosunku do roku poprzedniego. Zmienił się również rozkład geograficzny inwestycji. Tendencja spadkowa dotyczyła tylko krajów rozwiniętych, natomiast gospodarki rozwijające się niezmiennie odnotowywały wzrost.

\section{Globalne przepływy FDI w latach 2006-2012 (w mln USD)}

RYSUNEK 1.

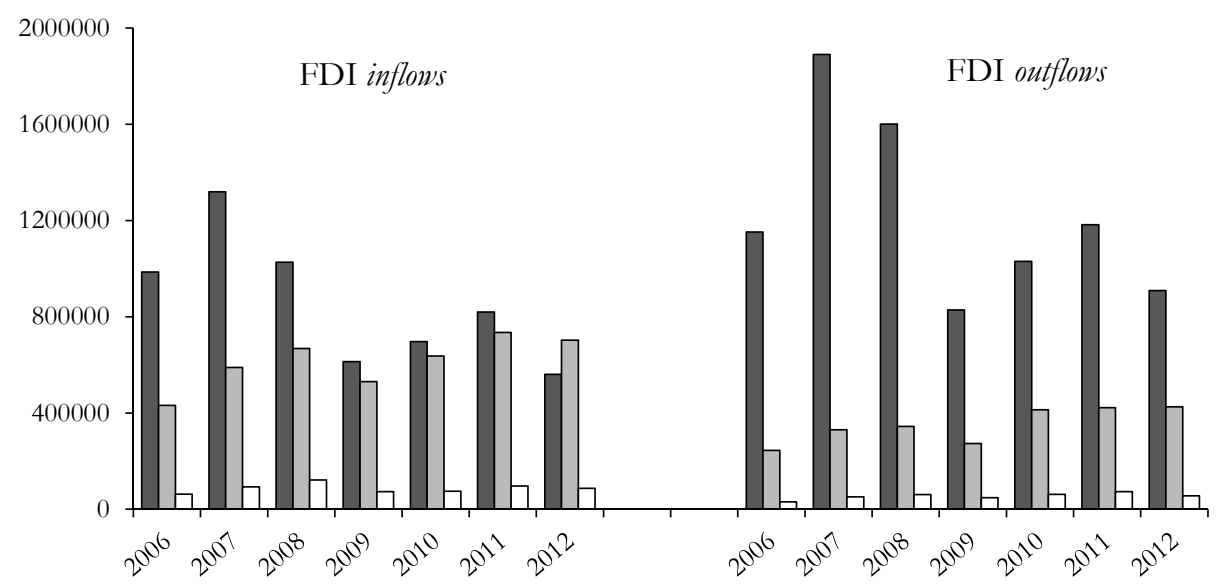

$\square$ Kraje rozwinięte/Developed economies $\quad \square$ Kraje rozwijające się/Developing economies

$\square$ Pozostałe kraje/World n.e.s.

Źródło: opracowanie własne na podstawie danych UNCTAD, UNCTADstat.

Przyczyn takiej sytuacji należy szukać m.in. w zmniejszeniu się ilości i wartości fuzji i przejęć (Mergers and Acquisitions - M\&A), będących główną formą FDI w grupie krajów wysoko rozwiniętych, oraz w obniżeniu wartości akcji na giełdach, a tym samym wartości zawieranych transakcji. Niepewna sytuacja i słaby rynek akcji podważały wśród kadry zarządzającej wiarę w perspektywy rozwoju i możliwość osiągania zadowalających zysków, co wpłynęło na plany dotyczące M\&A. Natomiast w krajach rozwijajacych się inwestycje zagraniczne dotyczyły przede wszystkim tran- 
sakcji typu greenfield, które sa zaplanowane i charakteryzują się relatywnie stabilnymi kosztami inwestycyjnymi. Miało to również przełożenie na mniejszą o połowę dynamikę spadku wartości przepływów w 2009 roku, a w 2010 roku na ich większy wzrost.

We wrześniu 2008 roku, po upadku Lehman Brothers - jednej z największych instytucji finansowych w Stanach Zjednoczonych, kryzys finansowy burzliwie wszedł w nowa fazę, a gospodarki krajów wysoko rozwiniętych dotknęła recesja. Jej skutkiem był drastyczny spadek wartości kapitału transferowanego w formie inwestycji $(-22,2 \%$ outflows, $-15,3 \%$ inflows). Negatywny wpływ wynikał z jednej strony z ograniczonego dostępu do finansowania inwestycji, a z drugiej z ogólnego klimatu inwestycyjnego, niedostatecznej atrakcyjności rynków i podwyższonego ryzyka percepcji [World Investment Report..., 2009, s. 5]. Warto podkreślić, iż pomimo zawirowań na amerykańskim rynku finansowym, USA zachowały pozycję lidera wśród odbiorców inwestycji (16,9\% outflows), a ich wartość wzrosła aż o 41,9\% do poziomu $215952 \mathrm{mln}$ USD. Przyczynił się do tego m.in. proces wycofywania kapitału przez firmy-matki ze swoich filii, a najpotężniejsze korporacje pochodzą właśnie z USA.

Stosunkowo wysoką odpornością na turbulencje finansowe cechowały się kraje: Afryki ${ }^{8}$, Ameryki Południowej oraz Karaiby, w tym przede wszystkim: Brazylia, Chile, Kolumbia i Argentyna. Jest to zrozumiałe ze względu na relatywnie mniejsze ich powiązania z amerykańskim systemem bankowym, a także rosnące ceny surowców. W 2008 roku na obszarze państw rozwijających się, mimo niewielkiego wzrostu rzędu 13,4\%, zlokalizowano inwestycje o wartości $668438 \mathrm{mln}$ USD (rysunek 1). Jednocześnie zaobserwowano ich rosnąca aktywność jako dawców kapitału o 4,2\%, w wyniku której ostatecznie wypływ FDI zamknął się w kwocie 344034 mln USD.

Przyglądając się czynnikom instytucjonalnym, można zaryzykować stwierdzenie, że kryzys miał ograniczony wpływ na politykę w zakresie FDI, ponieważ nie one były jego przyczyna. Jednak zmiany wprowadzone przez niektóre rządy w odpowiedzi na kryzys, tj.: pakiety stymulacyjne, programy pomocowe, dalsze redukcje w wysokości podatku pobieranego od firm zagranicznych, prywatyzacja przedsiębiorstw, liberalizacja reżimu kursowego [World Investment Report..., 2009, s. xxiv], zdaniem autorów WIR 2009, mogły spowodować względną stabilizację, a być może nawet poprawę kluczowych czynników rozwoju. W przeciwnym kierunku działała realizowana polityka protekcjonizmu inwestycyjnego, faworyzująca krajowych inwestorów. Powstały w ten sposób wysoki udział wartości krajowej mógłby ograniczyć napływ inwestycji zagranicznych. Obawy analityków stały się faktem w obliczu danych odnotowanych w kolejnym roku.

8 Ważnym odbiorcą były kraje afrykańskie, w tym: Nigeria, RPA, Kongo, Ghana, Gwinea i Madagaskar. Rządy państw afrykańskich wykazały się większym zaangażowaniem i wsparciem instytucjonalnym niż w latach poprzednich. Dotyczyło to przede wszystkim zmian regulacyjnych w polityce ochrony środowiska mającej kluczowe znaczenie w przyciaganiu FDI. Na przykład w Egipcie wprowadzono liczne, wolne strefy przemysłowe, w Kenii uchwalono nowe przepisy związane z konkurencja, bardziej restrykcyjne wobec monopoli. Równocześnie podpisano liczne porozumienia bilateralne, uwzględniające działania na rzecz promocji FDI (np. Afryka-Indie), [World Investment Report..., 2009, s. 48]. 
W 2009 roku kryzys finansowy rozszerzył się na inne gospodarki i stał się priorytetową determinantą zmian, oddziałując negatywnie zarówno na zdolność przedsiębiorstw do podejmowania działalności poza granicami kraju macierzystego, jak i na atrakcyjność inwestycyjna regionu. Odnotowano rekordowy spadek globalnych wartości napływu i odpływu kapitału w formie FDI $(-33,0 \%,-42,3 \%)$, który, podobnie jak to miało miejsce we wcześniejszych latach, był w większym stopniu udziałem grupy państw wysoko rozwiniętych. Powodowało to dalszą reorientację w kierunkach przepływów, zmniejszająca poziom polaryzacji geograficznej na rzecz krajów rozwijających się, które wchłonęły 43,6\% kapitału (530 289 mln USD) i stały się źródłem 23,8\% globalnych inwestycji (273 $401 \mathrm{mln}$ USD). Akceleratorem tych zmian przypuszczalnie była postępująca modyfikacja przepisów prawa krajowego i ich bardziej otwarty charakter, w tym przede wszystkim w: Azji Południowo-Wschodniej, Oceanii i Afryce (łącznie wprowadzono 110 nowych uregulowań w 55 krajach). Coraz bardziej aktywnym graczem na arenie międzynarodowej były kraje BRIC (Brazylia, Rosja, Indie i Chiny). Ich udział w generowaniu transferowanych wartości w formie FDI zwiększył się od 2000 roku niemal dziesięciokrotnie do prawie 9\% w 2008 roku [World Investment Report..., 2010, s. 7].

Względne ożywienie w poziomie globalnego transferu kapitału w formie bezpośrednich inwestycji zagranicznych nastapiło w 2010 roku (+13,5\% FDI inflows, $+30,9 \%$ FDI ouflows), przy czym było to głównie wynikiem drastycznego spadku w 2009 roku (rysunek 1). Jednakże świadczy to o tym, iż kryzys, pomimo poważnego wpływu na FDI, nie powstrzymał postępującego procesu internacjonalizacji produkcji i był on z powodzeniem kontynuowany również w kolejnym roku. Z rozkładu geograficznego wartości przepływów FDI można wnioskować o umocnieniu się tendencji do zmniejszenia się przepaści pomiędzy spolaryzowanymi regionami. W efekcie tych zmian w 2012 roku, po raz pierwszy w historii, gospodarki rozwijające się wysunęły się na prowadzenie w pozyskiwaniu FDI. Przyciagnęły one 52,0\% inwestycji, a odpowiadały za niemal jedną trzecią odpływu inwestycyjnego.

Lata 2010-2011 to czas neutralizacji negatywnych implikacji kryzysu finansowego, który swoje apogeum osiagnał w 2009 roku. Obok napięć na rynku finansowym i kryzysu zadłużeniowego gospodarek europejskich, pojawiły się także nowe wyzwania o charakterze pozaekonomicznym, w tym m.in.: katastrofy przyrodnicze w Islandii, zagrożenia nuklearne w Japonii, rewolucje i niepokoje w Afryce Północnej i na Bliskim Wschodzie, które zwiększyły obszar ryzyk i niepewności w podejmowaniu działalności gospodarczej za granica. Wskazane zakłócenia miały swoje przełożenie zarówno na relatywnie niskie tempo wzrostu gospodarczego, jak i na dynamikę globalnych przepływów finansowych, zwłaszcza w 2011 roku. W obliczu niekorzystnych uwarunkowań w raporcie UNCTAD z 2011 roku pojawił się apel, by rządy państw kontynuowały strategię liberalizacji polityki inwestycyjnej, podkreślając szczególną w tym względzie rolę dobrowolnych standardów odpowiedzialności społecznej korporacji (Corporate Social Responsibility - CSR), [World Investment Report..., 2011, s. 111, 120].

Kolejny rok przyniósł względne spowolnienie w gospodarce światowej. Tempo wzrostu globalnego GDP spadło o 0,5 p.p. do poziomu 2,24\%. Tendencje malejące objęły również wartość FDI (rysunek 1). Odpływy w 2012 roku osiągnęły poziom 
1390956 mln USD, tj. o 17,1\% mniej niż w roku poprzednim, a napływ zamknął się kwotą 1350925 mln USD (-18,2). Spadek był przede wszystkim udziałem krajów rozwiniętych (odpowiednio: -23,1\%; -31,6\%), w tym głównie: Szwajcarii, Holandii, Finlandii i Japonii. W globalnym rankingu miejsc najbardziej atrakcyjnych dla inwestorów nadal prym wiodły USA. W czołówce także znalazły się: Chiny, Niemcy, Hiszpania, Francja i Szwecja. Jednocześnie na liście inwestorów prowadziły Stany Zjednoczone z udziałem równym $23,6 \%$. Kraje rozwijające się, charakteryzujące się: rosnącym popytem konsumpcyjnym, relatywnie niższymi kosztami pracy i dostępem do surowców naturalnych, przyciagnęły kapitał zagraniczny o wartości $702825 \mathrm{mln}$ USD.

Tempo zmian w globalnych przepływach FDI, jakie następowało wskutek niepewnej sytuacji gospodarczej na rynku światowym, było wyraźnie zbieżne z tempem wzrostu zagregowanego GDP i handlu międzynarodowego. Na charakter i siłę tej zależności wskazuje znak dodatni obliczonego współczynnika korelacji Pearsona. Przyjmował on wartości w przedziale od 0,79 do 0,95 (rysunek 2). Najwyższy stopień korelacji odnotowano w przypadku relacji GDP i FDI inflows, który dla świata wyniósł 0,86 . Napływ bezpośrednich inwestycji zagranicznych w krajach rozwiniętych był relatywnie mniej uzależniony od czynników makroekonomicznych $(\mathrm{R}=0,78)$, co poniekąd tłumaczy niezmienne zainteresowanie inwestorów rynkiem amerykańskim, pomimo niepewnej sytuacji finansowej USA. W przypadku krajów rozwijających się można mówić o praktycznie pełnym sprzężeniu zwrotnym między tempem wzrostu gospodarczego a translokalizacją kapitału $(\mathrm{R}=0,93)$. Równie dychotomiczny rozkład związków korelacyjnych pomiędzy analizowanymi grupami krajów zaobserwowano w odniesieniu do FDI outflows. Podejmowanie decyzji o przyjęciu bądź realizacji bezpośredniej inwestycji zagranicznej było spójne ze zmianami w poziomie obrotów handlowych krajów rozwiniętych $(\mathrm{R}=0,8)$.

RYSUNEK 2.

\section{Stopień korelacji zmian w przepływach: FDI, GDP i handlu międzynarodowym} w latach 2006-2012

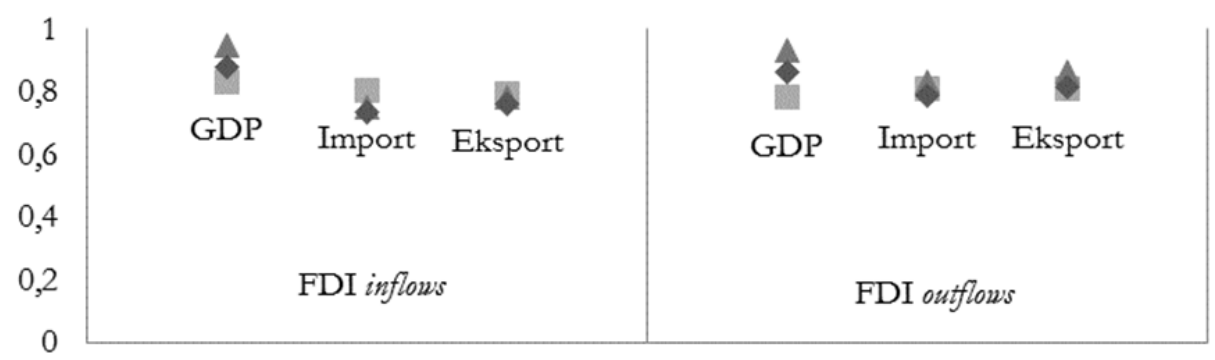

Kraje rozwinięte/Developed economies

$\Delta$ Kraje rozwijające się/Developing economies

$\bullet$ Świat/World

Źródło: obliczenia własne na podstawie danych UNCTAD, UNCTADstat. 
Uzupełnieniem analizy przepływów FDI jest zestawienie wielkości skumulowanych (FDI inwardstock, FDI outwardstock). Choć w poszczególnych latach transfer kapitału wykazywał się zmienną dynamiką, to całkowity poziom napływu FDI zwiększył się o 58,4\% z 14405342 mln USD w 2006 roku do 22812680 mln USD w 2013 roku (rysunek 3). Zmniejszająca się biegunowość w zakresie realizacji inwestycji między krajami rozwiniętymi a rozwijającymi się była również widoczna w dynamice zmian skumulowanych ich wartości. Gospodarki wschodzące do 2012 roku wchłonęły kapitał w wysokości $744523 \mathrm{mln}$ USD $(+124,1 \%)$. Odpływy FDI przyjmowały zbliżone wartości sumaryczne dla świata - w 2012 roku wyniosły 23592739 mln USD, czyli o 49,6\% więcej w porównaniu z sytuacją sprzed 6 lat. Ponadprzeciętna aktywność inwestorów z krajów rozwijających się spowodowało wzrost wartości wywożonego kapitału o $130,9 \%$.

RYSUNEK 3.

Wartość skumulowana FDI na świecie w latach 2006-2012 (w mln USD)

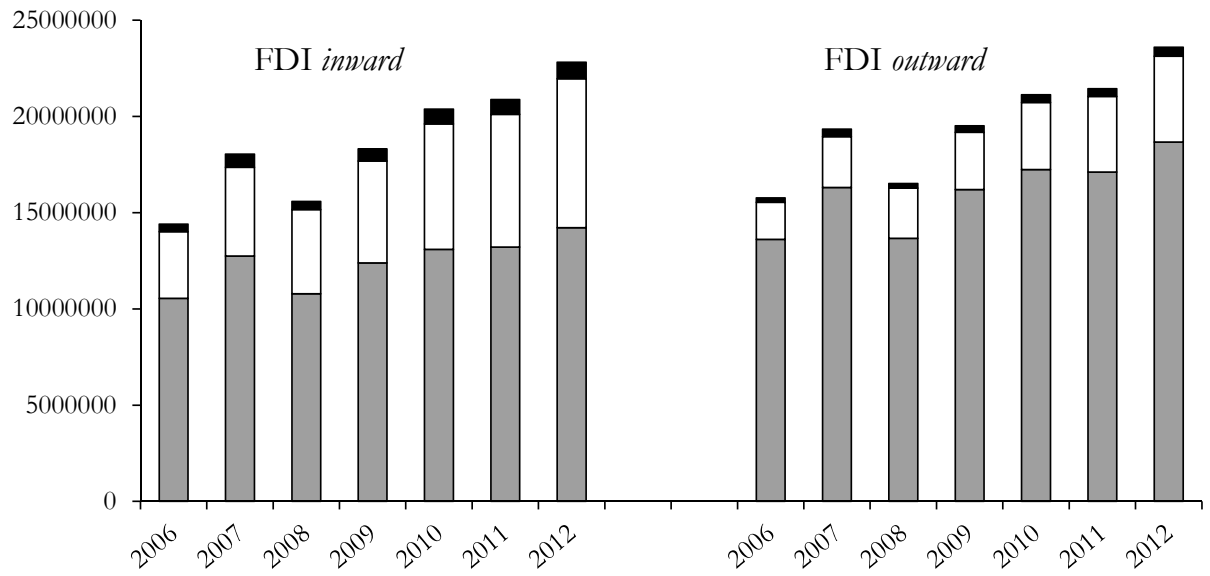

$\square$ Kraje rozwinięte/Developed economies $\quad \square$ Kraje rozwijające się/Developing economies

- Pozostałe kraje/World n.e.s.

Źródło: opracowanie własne na podstawie danych UNCTAD, UNCTADstat.

Mimo że proporcje w światowych przepływach FDI w tych dwóch grupach krajów wahały się, a ostatecznie zmieniły na rzecz gospodarek rozwijających się, to w latach 2006-2012 struktura podmiotowa skumulowanych wartości wykazywała względną stabilność ${ }^{9}$ i hegemonię gospodarek rozwiniętych. Do 2012 roku były one gospodarzem 62,3\% wszystkich inwestycji (wobec 73,3\% w 2006 roku) oraz wygenerowały łącznie 79,2\% FDI (wobec 86,3\% w 2006 roku). Jeśli kierunek i tempo reorien-

9 Średnioroczne tempo zmian udziałów w napływie i odpływie FDI wyniosło odpowiednio: w przypadku krajów rozwiniętych 2,3\% i 1,4\%, a w krajach rozwijających się 6,0\% i 7,7\%. 
tacji w strukturze podmiotowej utrzymają się, to najprawdopodobniej za kilka lat globalne wartości skumulowane FDI w analizowanych grupach będą kształtowały się na zbliżonym poziomie.

Analiza korelacji dowiodła, iż dynamika wartości skumulowanych inwestycji cechowała się zróżnicowanym stopniem zależności od fundamentalnych mierników ekonomicznej aktywności. Współczynnik przyjmował wartości zarówno dodatnie, jak i ujemne i mieścił się w przedziale od -0,44 do +0,56 (rysunek 4). Najwyższe bezwzględne poziomy, wskazujące na wyraźną korelację, odnotowano między tempem wzrostu zagregowanych wartości inwestycji a handlem międzynarodowym, zarówno dla gospodarek rozwiniętych, jak i dla świata. Współczynnik w przypadku tych relacji był ujemny, a zatem rosnąca dynamika wartości skumulowanych inwestycji implikowała malejące średnioroczne tempo zmian w handlu międzynarodowym. Świadczyć to może o czynnikach, które znalazły się u podstaw wyboru lokalizacji inwestycji.

Przypuszczalnie najważniejszym motywem ekspansji na rynki zagraniczne była strategia zarządzania, przede wszystkim podyktowana dostępem do nowych rynków zbytu. Podążanie za klientem było szczególnie ważne w odniesieniu do inwestycji w krajach rozwijających się, które wyróżniają się wysokim wzrostem popytu konsumpcyjnego. Tempo wzrostu zainwestowanego kapitału z tych państw wykazało dodatnia, umiarkowaną korelację wobec badanych mierników ekonomicznych. Praktycznie brak związku $(\mathrm{R}<0,1)$ odnotowano w relacji do globalnego GDP dla świata i krajów rozwiniętych oraz $\mathrm{w}$ handlu światowym w przypadku gospodarek rozwijających się.

RYSUNEK 4.

Stopień korelacji zmian globalnej wartości skumulowanej: FDI, GDP i handlu międzynarodowego w latach 2006-2012

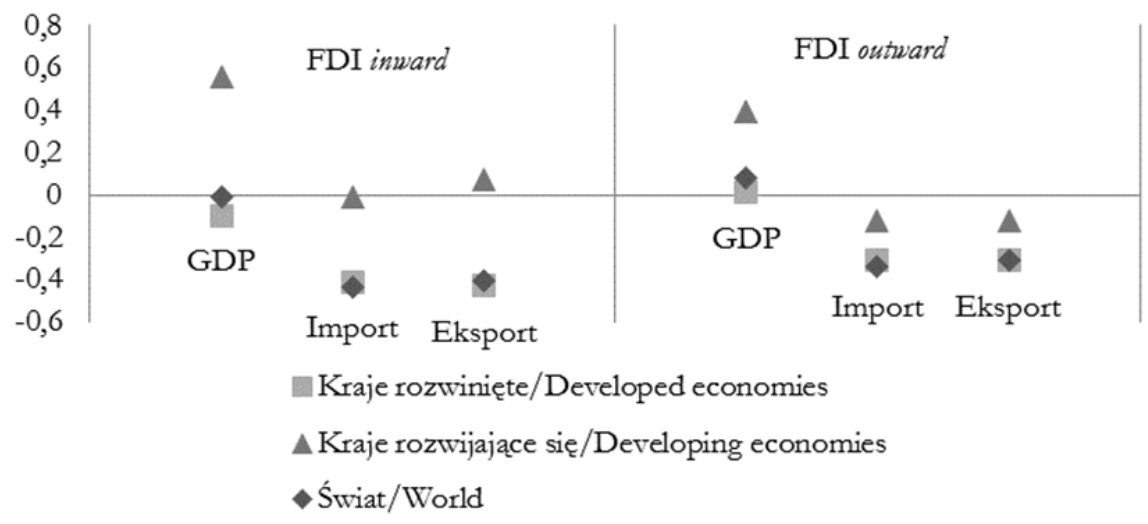

Źródło: obliczenia własne na podstawie danych UNCTAD, UNCTADstat.

Dodatkowych informacji na temat aktywności inwestycyjnej badanych regionów w kontekście destabilizacji czynników ekonomicznych dostarczyła analiza otwartości krajów na inwestycje. Wskaźnik, będący relacją przepływów FDI do GDP, pozwala na porównanie stopnia zaangażowania gospodarek w generowaniu inwestycji, wyrażone- 
go w procentowej wartości produktu krajowego brutto (rysunek 5). W badanych latach kraje rozwijające się charakteryzowały się dwukrotnie wyższą otwartością na inwestycje w porównaniu z gospodarkami rozwiniętymi. Stanowi to potwierdzenie dużej ich aktywności jako odbiorców transferowanego kapitału. Jednocześnie zwiększył się dysonans w wartości wskaźnika w porównaniu z krajami rozwiniętymi. Spośród przyczyn wywołujących taką sytuację należy podkreślić: ograniczenie możliwości rozwoju inwestycji $\mathrm{w}$ regionie państw rozwiniętych spowodowane wysokim poziomem kondensacji już istniejących zasobów inwestycyjnych, rosnąca atrakcyjność krajów rozwijających się pod względem miejsca lokowania kapitału wzmacniana polityką proinwestycyjna, a także procesy integracji i regionalizacji skutkujące podpisaniem licznych umów o współpracy. Poziom miernika uwydatnił również ogromną rolę bezpośrednich inwestycji zagranicznych w gospodarkach krajów rozwijających się oraz strukturalny, nierównomierny rozkład globalnych przepływów FDI.

RYSUNEK 5.

Wskaźnik otwartości gospodarki na inwestycje w latach 2006-2012 (w \%)

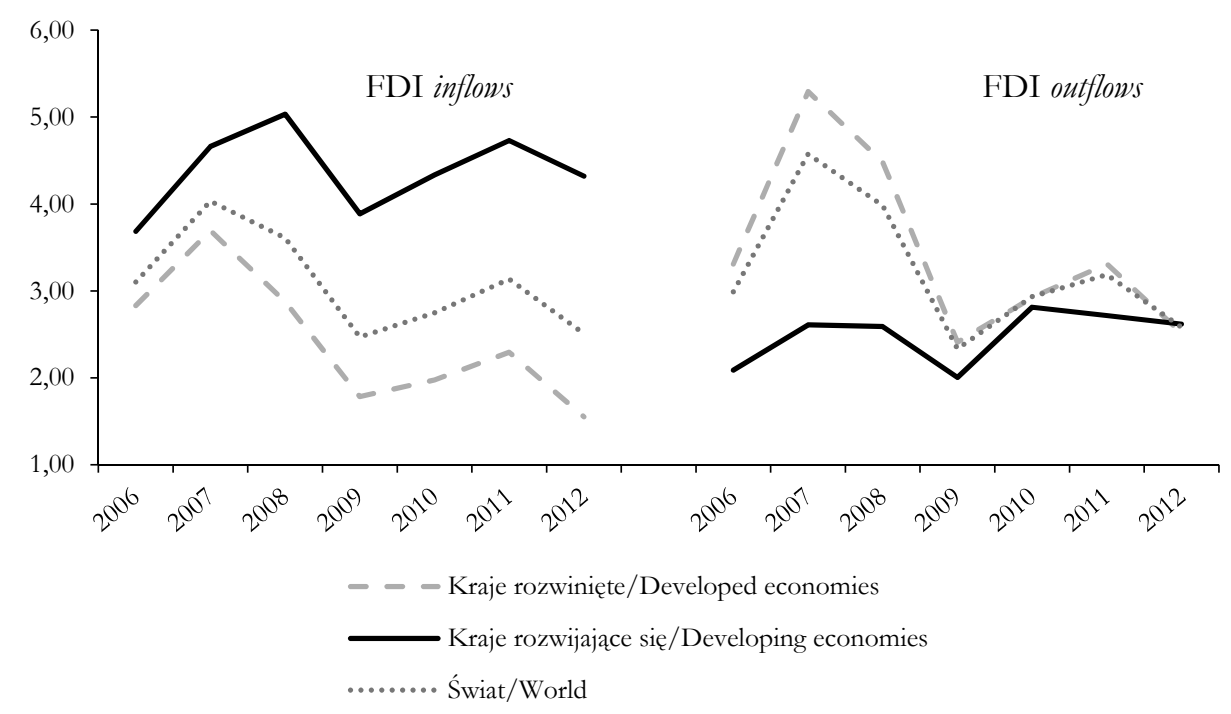

Źródło: obliczenia własne na podstawie danych UNCTAD, UNCTADstat.

Zdecydowanie odmiennie kształtował się wskaźnik otwartości dla odpływu kapitału. Jego wartości dowiodły tego, iż państwa rozwinięte uzyskiwały większe korzyści z procesów internacjonalizacji $\mathrm{w}$ porównaniu z pozostałymi państwami, przy czym przewaga ta zmniejszała się, a w 2012 roku tendencja została odwrócona. Jednocześnie wskaźnik otwartości gospodarki światowej na inwestycje charakteryzował się znaczną zmiennościa, będąca odzwierciedleniem turbulencji na rynku globalnym wywołanych kryzysem finansowym. 


\section{Podsumowanie}

Przeprowadzona analiza empiryczna globalnych przepływów i wartości skumulowanej bezpośrednich inwestycji zagranicznych, wsparta informacjami dotyczącymi zmian makroekonomicznych w wybranych grupach krajów w latach 2006-2012, potwierdziła założenie o odmienności przeobrażeń ilościowych w globalnych przepływach FDI. Jednak dowody na to mają charakter względnie ogólnikowy z uwagi na brak dywersyfikacji strukturalnej, to natomiast wymaga przeprowadzenia dalszych badań, bardziej szczegółowych, z uwzględnieniem analizy przedmiotowej i rodzajowej FDI ${ }^{10}$.

Uwarunkowania koniunkturalne stanowiły ważny czynnik określający dynamikę i kierunki przepływu bezpośrednich inwestycji zagranicznych. Tempo zmian było wyraźnie zbieżne $z$ tempem wzrostu zagregowanego GDP i handlu międzynarodowego, przy czym najwyższy stopień zależności zaznaczył się w przypadku relacji GDP i FDI inflows. Napływ bezpośrednich inwestycji zagranicznych był relatywnie mniej uzależniony od czynników makroekonomicznych w krajach rozwiniętych, natomiast w przypadku krajów rozwijających się można mówić o praktycznie pełnej korelacji między tempem wzrostu gospodarczego a ich aktywnościa jako inwestorów. Ponadto, podejmowanie decyzji o przyjęciu bądź realizacji bezpośredniej inwestycji zagranicznej było spójne ze zmianami w poziomie obrotów handlowych krajów rozwiniętych.

Poziom otwartości analizowanych grup krajów w latach 2006-2012 cechował się znaczną dywersyfikacją podmiotową i zmiennością. Gospodarki rozwijające się wykazywały się dwukrotnie wyższą otwartością na inwestycje w porównaniu z gospodarkami rozwiniętymi, a jednocześnie systematycznie zwiększały swoje zaangażowanie w proces internacjonalizacji macierzystych przedsiębiorstw. Doprowadziło to do zmniejszenia dysproporcji w strukturze geograficznej globalnych przepływów kapitalowych w formie FDI.

Niewątpliwie bezpośrednie inwestycje zagraniczne mają korzystny wpływ na rozwój gospodarczy krajów i regionów ${ }^{11}$, pomimo występujących zagrożeń. Potwierdzona, znaczna koincydencja zmian w wartości FDI i uwarunkowaniach koniunkturalnych powinna zatem stanowić wskazówkę dotycząca decyzji w zakresie polityki gospodarczej. Relatywnie szybka percepcja i interpretacja symptomów osłabienia koniunktury płynących z rynku mogłaby przyczynić się do utrzymania sprzyjającego klimatu

10 Dla wybranych krajów Unii Europejskiej badania takie przeprowadziła T. Kamińska [2013, s. 309-310]. Wyniki analizy względnych wskaźników podobieństwa struktury pozwoliły skonstatować, że ani niekorzystne uwarunkowania polityki ekonomicznej, ani skutki recesji nie wpłynęły na istotne przeobrażenia struktury branżowej FDI w większości krajów Unii Europejskiej. Istniejące, relatywnie niewielkie fluktuacje w tym zakresie miały charakter obiektywny, podążajacy raczej za zmianami w strukturze aktywności gospodarczej niż zmianami koniunktury.

11 Zdaniem autorów raportu UNCTAD z 2013 roku, ważnymi czynnikami, stymulującymi podejmowanie decyzji inwestycyjnych, są m.in.: rozwój infrastruktury, ograniczenie korupcji, wspieranie powiązań z gospodarką krajowa, budowa lokalnych instytucji R\&D, większa przejrzystość systemu prawnego, w tym w szczególności w odniesieniu do praw własności intelektualnej, większa spójność między polityką inwestycyjną a polityką rozwoju oraz zmiany w zakresie środków i metod zagranicznej polityki handlowej [World Investment Report..., 2013, s. 24, 26]. 
inwestycyjnego nawet w okresach makroekonomicznej destabilizacji. Kluczowe staje się zatem opracowanie mechanizmu „ssącego” kapitał zagraniczny i promującego kapitał pochodzenia krajowego.

\section{Literatura}

Aizenman J., Jinjarak Y., Park D., 2013, Capital Flows and Economic Growth in the Era of Financial Integration and Crisis, 1990-2010, „Open Economies Review”, t.. 24, nr 3, DOI: $\quad 10.1007 / \mathrm{s} 11079-012-9247-3$, https://link.springer.com/article/10.1007/ s11079-012-9247-3 [data wejścia: 18.02.2017].

Ancyparowicz G., 2009, Wplyw bezpośrednich inwestyci zagranicznych na wærost polskiej gospodarki w okresie poakcesyjnym, Główny Urząd Statystyczny, Departament Statystyki Finansów, Warszawa.

Balcerzak A. P., Żurek M., 2010, Analiza wplywu bespośrednich inwestycji zagranicznych na PKB i stope bezrobocia w Polsce w latach 1995-2010 za pomoca modelu VAR, „Roczniki Naukowe Wyższej Szkoły Informatyki i Ekonomii Towarzystwa Wiedzy Powszechnej", nr 1-2, Olsztyn.

Bilewicz E., 2011, Światony kryzys finansowy a naptyw kapitalu do krajón rozwijajacych sie, „Gospodarka, Zarządzanie, Srodowisko”, „Zeszyty Naukowe Uniwersytetu Szczecińskiego. Studia i Prace Wydziału Nauk Ekonomicznych i Zarządzania”, nr 24.

Borenszteina E., de Gregoriob J., Lee J.W., 1998, How does foreign direct investment affect economic growth?, "Journal of International Economics", t. 45, nr 1, 1 June 1998, http://www.sciencedirect.com/science/article/pii/S0022199697000330\%20111 [data wejścia: 20.01.2017].

Carkovic M.V., Levine R., 2002, Does Foreign Direct Investment Accelerate Economic Growth?, "U of Minnesota Department of Finance Working Paper", UC Berkeley, National Bureau of Economic Research (NBER), Available at SSRN, http://dx.doi.org/10.2139/ssrn.314924, [data wejścia: 17.03.2017].

Chowdhury A., Mavrotas G., 2006, FDI and growth: What causes what?, "The World Economy", no. 29(1).

Dunning J.H., 1998, Globalization, Trade and Foreign Direct Investment, Elsevier, Amsterdam.

Dzikowska M., Gorynia M., Jankowska B., 2015, Globalny krysys gospodarcsy - próba pomiaru efektów dla poszcrególnych krajón, „Ekonomista”, nr 6.

Firlej K.A., 2011, Źródła i przebieg kryyysu finansowego w Stanach Zjednoczonych $i$ Europie Zachodniej, „Roczniki Ekonomiczne Kujawsko-Pomorskiej Szkoły Wyższej w Bydgoszczy", t. 11, nr 4.

Folfas P., 2015, Bezpośrednie inwestycje zagraniczne i wrrost gospodarçy w państwach G-5 oraz BRICS - analiza praycsynowości w sensie Grangera, „Ekonomia XXI Wieku”, nr 3(7), DOI: 10.15611/e21.2015.3.02, http://bazekon.icm.edu.pl/bazekon/ element/ bwmeta1.element.ekon-element-000171394963?q=a9f9c390-b116-4647a099-ed1a 0b06f9ad\$11\&qt=IN_PAGE [data wejścia: 10.03.2017]. 
Globalizacja, krysys i co dalej?, 2010, G. Kołodko (red.), Wydawnictwo Poltext, Warszawa.

Gorynia M., 2016, Miejsce gospodarki polskiej w gospodarce Unii Europejskiej w latach 20032014, „Przegląd Zachodni”, nr 4, http://www.artykul61.pte.pl/pliki/2/12/Przeglad_Zachodni_Gorynia_2016.pdf [data wejścia: 12.02.2017].

Gurgul H., Lach Ł., 2009, Zwiazki praycsynowe pomiedsy beapośrednimi inwestycjami zagranicżymi w Polsce a podstawowymi wskaźnikami makroekonomicznymi (czesśc teoretycz̨na), „Ekonomia Menedżerska”, nr 6.

Gurgul H., Lach Ł., 2009, Zwiqzki praycsynowe pomiedsy beapośrednimi inwestycjami zagranicznymi w Polsce a podstawonymi wskaźnikami makroekonomicznymi (wyniki badañ empirycznych), „Ekonomia Menedżerska”, nr 6.

Handbook of Statistics oraz baza FDIStat, UNCTAD, http:/ /unctadstat.unctad.org/EN/ [data wejścia: 25.09.2015].

Jasiniak M., 2014, Beappośrednie inwestycje zagraniczne w Polsce w warunkach miedzyynarodowego krysysu gospodarczego, „Finanse, Rynki Finansowe, Ubezpieczenia”, „Zeszyty Naukowe Uniwersytetu Szczecińskiego", nr 67.

Kamińska T., 2013, Struktura branżowa bezpośrednich inwestygi zagranicznych a kryzys finansowy, „Ekonomia”, Prace Naukowe Uniwersytetu Ekonomicznego we Wrocławiu, nr 305, http://www.dbc.wroc.pl/Content/28297/Kaminska_Struktura_ Budzetowa_Bezposrednich_Inwestycji_Zagranicznych_2013.pdf [data wejścia: 09.05.2017].

Kamińska-Blichowska T., 2016, Bezpośrednie innestycje zagraniczne w wybranych grupach krajón w latach 2007-2014, „Zeszyt Naukowy Wyższej Szkoły Zarządzania i Bankowości w Krakowie", nr 39, http://yadda.icm.edu.pl/yadda/element/bwmeta1. element.desklight-30bf3fa2-f2db-442b-b13f-f085571a745a/c/www.zeszytnaukowy. pl-1 [data wejścia: 26.03.2017].

Karaszewski W., 2004, Bezpośrednie inwestycje zagraniczne, Polska na tle swiata, Wydawnictwo Dom Organizatora, Torun.

Kłysik-Uryszek A., 2010, Bezpośrednie inwestycje zagraniczne w gospodarce regionu. Teoria ipraktyka, CeDeWu, Warszawa.

Kłysik-Uryszek A., 2012, Zmiany zaangażonania innestorón zagranicznych w Polsce - wplyw kryzysu gospodarczego, „Acta Universitatis Lodziensis, Folia Oeconomica”, 273, http://dspace.uni.lodz.pl/xmlui/bitstream/handle/11089/2111/Agnieszka\%20 Kłysik-Uryszek\%20187-197.pdf?sequence=1\&isAllowed=y [data wejścia: 03.02.2017].

Kłysik-Uryszek A., 2013, Zagraniczna ekspansja kapitatowa polskich przedsiębiorstw, „Zarządzanie i Finanse”, t. 2, nr 2, Wydział Zarządzania, Uniwersytet Gdański, http://zif.wzr.pl/pim/2013_2_2_13.pdf [data wejścia 28.01.2017].

Kowalski T., 2013, Globalisation and transformation in Central European Countries: the Case of Poland, Poznań University of Economics Press, Poznań.

Krzak M., 2009, Sytuacja na miedsynarodowych rynkach finansowych, [w:] Kryzys globalny: pocratek cry koniec?, J. Winiecki (red.), Wydawca Regan Press, Gdańsk.

Li X., Liu X., 2005, Foreign Direct Investment and Economic Growth: An Increasingly Endogenous Relationship, "World Development", t. 33, nr. 3, http://www.sciencedirect.com/ science/article/pii/S0305750X04002013 [data wejścia: 27.02.2017]. 
Liu X., Burridge P., Sinclair P. J. N., 2002, Relationships between economic growth, foreign direct investment and trade: evidence from China, "Journal Applied Economics", vol. 34, Iss. 11, http://dx.doi.org/10.1080/00036840110100835 [data wejścia: 15.03.2017].

Majewska M., Grala J., 2003, Zagranične innestycje bezpośrednie a wærost gospodarçy Polski, [w:] Bespośrednie innestyyje zagranicz̨ne w Polsce, W. Karaszewski (red.), Wydawnictwo Uniwersytetu Mikołaja Kopernika, Toruń.

Markovskaya E.I., Anoshkina E.S., 2016, Analysis of the Influence of the Foreign Direct Investments on the Economic Growth in the Developed and Developing Countries, HSE Working Paper, Social Science Research Network, https://publications.hse.ru/en/ preprints/199303177 [data wejścia: 04.042017].

Marona B., Bieniek A., 2013, Wykorsystanie modelu VECM do analizy wptywu bezpośrednich inwestyciji zagranicznych na gospodarke Polski w latach 1996-2010, Acta Universitatis Nicolai Copernici Ekonomia, t. 44, nr 2, DOI: http://dx.doi.org/10.12775/ AUNC_ECON.2013.022.

Misala J., 1990, Teorie miedzynarodowej mymiany gospodarczej, Wydawnictwo Naukowe PWN, Warszawa.Misztal P., 2012, Bezpośrednie inwestycje zagraniczne jako çynnik wzrostu gospodarczego w Polsce, „Finanse”, czasopismo Komitetu Nauk o Finansach PAN, nr 1(5), http://www.knfpan.pan.pl/images/stories/Finanse _5-1-P.Misztal.pdf [data wejścia: 26.02.2017].

Nair-Reichert U., Weinhold D., 2001, Causality tests for cross-country panels: a new look at FDI and economic growth in developing countriesy, "Oxford Bulletin of Economics and Statistics”, t. 63, nr 2, 0305-9049, http://onlinelibrary.wiley.com/doi/10.1111/ 1468-0084.00214/pdf [data wejścia: 13.02.2017].

Oczkowska R., 2013, Miedsynarodowa ekspansja przedsiebiorstw w warunkach globalizacji. Motyny - Strategie - Tendencje, Wydawnictwo Difin, Warszawa.

OECD, Glossary of foreign direct investment terms and definitions, http://www.oecd.org/ daf/inv/investmentfordevelopment/2487495.pdf [data wejścia: 19.01.2016].

Onufer A., 2011, Bezpośrednie inwestycje zagraniczne w krajach Grupy Wyszebradzkeiej w okeresie krysysu gospodarczego, Materiały z międzynarodowej konferencji, Wrocław, 23-24 kwietnia 2010 roku, Prawnicza i Ekonomiczna Biblioteka Cyfrowa, http://www.bibliotekacyfrowa.pl/dlibra/publication?id=29858\&from=\&dirids= $1 \& \mathrm{tab}=1 \& \mathrm{lp}=1 \& \mathrm{QI}=8 \mathrm{~A} 087931 \mathrm{D} 612 \mathrm{C} 65 \mathrm{CC} 32 \mathrm{C} 2 \mathrm{~A} 41 \mathrm{~F} 11 \mathrm{DB} 097-1$ [data wejścia: 21.03.2017].

Oziewicz E., 1998, Zagraniczne inwestycje beapośrednie w rozwoju Azji PotudniowoWschodniej (ASEAN), Wydawnictwo Uniwersytetu Gdańskiego, Gdańsk.

Pera B., 2012, Bezpośrednie inwestycje zagraniczne Unii Europejskiej a globalny kryzys gospodarczy, „Studia Ekonomiczne. Międzynarodowe Stosunki Gospodarcze - Integracja regionalna w Europie i na świecie", nr 123, Uniwersytet Ekonomiczny, Katowice, http://ue.katowice.pl/fileadmin/_migrated/content_uploads/11_B.Pera_Bezpo srednie_Inwestycje....pdf [data wejścia: 16.02.2017].

Ptaszyńska B., 2015, Inwestycje zagraniczne caynnikiem wzrostu gospodarczego w Polsce, „Wiadomości Statystyczne”, nr 2, http://yadda.icm.edu.pl/yadda/element/ bwmeta1. element.ekon-element-000171333407/c/WS_02_2015_02_Barbara_ PTASZYNSKA__Inwestycje_zagraniczne_czynnikiem_wzrostu_gospodar- 
czego_w_Polsce.pdf [data wejścia: 19.05.2017].

Puchalska A., 2012, Krysys gospodarçy a naplyw beapośrednich inwestygi zagranicznych do Polski, „Nierówności Społeczne a Wzrost Gospodarczy”, nr 24, https://ur.edu.pl/ file/16774/7.pdf [data wejścia: 05.02.2017].

Rosati D., 2009, Praycayny i mechanizm kryzysu finansowego w US A, „Ekonomista”, nr 3.

Różański J., 2013, Wplyw światowego kryzysu ekonomicznego na bezpośrednie inwestycje zagraniczne w Polsce, „Acta Universitatis Nicolai Copernic i Ekonomia”, 44(1) DOI: http://dx.doi.org/10.12775/AUNC_EKON.2013.004.

Różański J., 2014, Zmiany w przeptywach bespośrednich inwestycji zagranicznych konsekwencje dla Polski i swiata, „Zarządzanie i Finanse”, t. 4, Wydawnictwo: Wydział Zarządzania, Uniwersytet Gdański, http://zif.wzr.pl/pim/2014_4_22.pdf [data wejścia: 21.01.2017].

Rymarczyk J., 2004, Internacjonalizacja i globalizacja przedsiębiorstwa, Polskie Wydawnictwo Ekonomiczne, Warszawa.

Świerkocki J., 2011, Rola bespośrednich inwestycii zagranicznych w ksztaltowaniu aktualnego $i$ prayszzłego profilu gospodarczego województwa tódそkiego, Lódzkie Towarzystwo Naukowe, Lódź.

Świerkocki J., 2011, Zarys ekonomii miedzynarodowej, Polskie Wydawnictwo Ekonomiczne, Warszawa.

Szydło W., 2013, Globalny krysys 2007-2009 w swietle podejścia ortodoksyjnego - uybrane problemy, „Optimum. Studia Ekonomiczne”, nr 3 (63), Wydawnictwo Uniwersytetu w Białymstoku, http://repozytorium.uwb.edu.pl/jspui/bitstream/11320/688/ 1/ 01_Wiktor\%20Szydło.pdf [data wejścia: 09.04.2017].

Wang M. M., Sunny Wong M. C., 2009, What Drives Economic Growth? The Case of Cross-Border M\&A and Greenfield FDI Activities, "KYKLOS", t. 62, nr 2, 316-330, DOI: 10.1111/j.1467-6435.2009.00438.x, http://onlinelibrary.wiley.com/doi/10.1111 /j.1467-6435.2009.00438.x/epdf [data wejścia: 12.02.2017].

Witkowska J., 1996, Bezpośrednie inwestycje zagraniczne w Europie Środkowowschodniej. Próba interpretacji na gruncie teorii bespośrednich inwestycji zagranicznych i teorii integracji, $\mathrm{W}_{\mathrm{y}-}$ dawnictwo Uniwersytetu Lódzkiego, Łódź.

World Investment Repor t2009 - Transnational Corporations, Agricultural Production and Development, UNCTAD, UN, New York and Geneva 2009, http://unctad.org/ en/Docs/wir2009_en.pdf [data wejścia: 18.09.2014].

World Investment Report 2007 - Transnational Corporations, Extractive Industries and development, UNCTAD, UN, New York and Geneva 2007, http://unctad.org/en/ Docs/wir 2007_en.pdf [data wejścia: 04.09.2014].

World Investment Report 2008 - Transnational Corporations, and the Infrastructure Challenge, UNCTAD, UN, New York and Geneva 2008, http://unctad.org/en/Docs/wir 2008_en.pdf [data wejścia: 09.09.2013].

World Investment Report 2010 - Investing in a low-carbon economy, UNCTAD, UN, New York and Geneva 2010, http://unctad.org/en/Docs/wir2010_en.pdf [data wejścia: 22.09 .2014 ] 
World Investment Report 2011 - Non-Equity Modes of International Production and Development, UNCTAD, UN, New York and Geneva 2011, http://unctad.org/en/ Publications Library/wir2011_en.pdf [data wejścia: 25.10.2015].

World Investment Report 2013- Global V alue Chains: Investment and Trade for Development UNCTAD, UN, New York and Geneva 2013, http://unctad.org/en/Publications Library/wir2013_en.pdf [data wejścia: 16.11.2015].

Wpływ rožoju spotecznego na handel i inwestycje zagraniczne. Prsypadek krajón Europy Środkowej i Wschodniej, 2012, J. J. Michałek, M. Brzozowski, A. Cieślik (red.), Polskie Wydawnictwo Ekonomiczne, Warszawa.

Wypych M., 2016, Inwestyge zagraniczne w Polsce w warunkach destabilizacij makroekonomicz$n e j$, „Annales Universitatis Mariae Curie-Skłodowska, sectio H - Oeconomia”, 49(4), DOI: http://dx.doi.org/10.17951/h.2015.49.4.719.

Wyrzykowska M., 2010, Bezpośrednie inwestycje zagraniczne w "nowych krajach” Unii Europejskiej - na prayykładzie Polski, Toruńskie Studia Międzynarodowe, "Międzynarodowe Stosunki Ekonomiczne", nr 1(3), http://apcz.pl/czasopisma/index.php/ TSM/article/viewFile/3462/3459 [data wejścia: 18.02.2017].

Zioło Z., 2014, Wphyw światowego kryzysu na tempo wrrostu gospodarki $i$ swiatonych korporacii, [w:] Wplyw kryzysu gospodarczego na przemiany struktur przemystonych, Z. Zioło i T. Rachwał (red.), Prace Komisji Geografii Przemysłu Polskiego Towarzystwa Geograficznego, t. 27, Warszawa-Kraków, http://prace-kgp.up.krakow.pl/article/view/ 2130/ 1856 [data wejścia: 17.03.2017].

Zorska A., 1998, Ku globalizacji? Przemiany w korporacjach transnarodonych $i$ gospodarce swiatowej, Wydawnictwo Naukowe PWN, Warszawa.

Żmuda M., 2012, The determinants of Chinese outward foreign direct investment to developing countries, "Innovation Sources of Economies in Eastern Asia", Prace Naukowe Uniwersytetu Ekonomicznego we Wrocławiu, nr 256, Wrocław, http://www.dbc. wroc.pl/Content/17964/Zmuda_The_Determinants_Of_Chinese_Outward_ Foreign_Direct_2012.pdf [data wejścia: 17.03.2017]. 